Vol.45, N. 2 : pp. 209 - 217, June 2002

ISSN 1516-8913 Printed in Brazil

AN INTERNATIONAL JOURNAL

\title{
Water Quality of the Canchim's Creek Watershed in São Carlos, SP, Brazil, Occupied by Beef and Dairy Cattle Activities
}

\author{
Odo Primavesi ${ }^{1 *}$; Alfredo Ribeiro de Freitas ${ }^{1}$; Ana Cândida Primavesi ${ }^{1}$ and Haydée Torres \\ de Oliveira ${ }^{2}$ \\ ${ }^{1}$ Southeast-Cattle Research Center; Embrapa; P. O. Box 339; CEP 13560-970; São Carlos - SP - Brazil. \\ ${ }^{2}$ Department of Hydrobiology; Federal University of São Carlos; P. O. Box 676; CEP 13565-905; São Carlos - SP - \\ Brazil
}

\begin{abstract}
The Canchim's creek watershed in São Carlos, SP, Brazil, was chosen to evaluate water quality affected by dairy and beef cattle production systems based on tropical pasture. The water samples were collected monthly, during three years, at six sampling points: spring in a tropical forest, spring in an intensive dairy production system, two dam springs, and stream water upward and at the delta. Results showed differences $(P<0.01)$ among sampling points for the mean parameters. True color, hardness, turbidity, electric conductivity, alkalinity, pH, chemical oxygen demand and consumed oxygen explained well differences among sampling points. According to current legislation standards, water quality fitted with most of the established parameters for class 2, with exception of phosphate and iron. The high levels of total phosphorus, except in the forest spring, classified this water in an eutrophic class, even where soil and water conservation practices were considered adequate.
\end{abstract}

Key words: Dairy cattle, Beef cattle, Intensive management, Pasture, Water quality, Watershed

\section{INTRODUCTION}

Monitoring water quality in watersheds, trying to detect the diffuse impact of agricultural activities, the causes and solutions to reduce or avoid them, have been studied intensively in the northern hemisphere, especially cattle farming (Johnes et al., 1996; Chokmani \& Gallichand, 1997; Zhang \& Essex, 1997), with the phosphorus problem (Jaworski et al., 1992; Cornish et al., 1996; Heathwaite \& Johnes, 1996; Nash \& Murdoch, 1997), nitrate (Jaworski et al., 1992; Heathwaite \& Johnes, 1996) and fecal coliforms (Howell et al.,
1995; Edwards et al., 1997). In Brazil, most of the studies were done on limnology, considering aspects of soil use and occupation in the drainage basins of the studied water streams (Sé, 1992; Rios, 1993; Santos 1993a,b; Teixeira, 1993; Rios \& Calijuri, 1995; Salati, 1996).

There is an intensive dairy production system at the Southeast-Cattle Research Center in São Paulo State, using tropical grasses, high level of inputs and high stocking rate with high production of feces, a potential pollution source of water bodies. This system has been used as a model for dairy farmers from many Brazilian states, which want to intensify their activities. Thus, this requires

\footnotetext{
${ }^{*}$ Author for correspondence
} 
attention from the viewpoint of sustainability and environmental quality.

The goal of this work was to study impacts of this production system located at the head of the Canchim's creek watershed on the water quality in comparison to other managed areas. Twenty four variables used by the sanitation laboratory to evaluate the water quality, mainly nitrate and phosphate, were monitored during 36 months to verify their correlation to intensity of soil use and conservation.

\section{MATERIALS AND METHODS}

\section{The sampling points}

The study area was the Canchim's creek watershed, located in the farm owned by Southeast-Cattle Research Center of Embrapa, in São Carlos, São Paulo state, Brazil, at the latitudes $21^{\circ} 54^{\prime}$ and $22^{\circ} 00^{\prime} \quad \mathrm{S}$ and longitudes $47^{\circ} 52^{\prime}$ and $47^{\circ} 48^{\prime} \mathrm{W}$, with a surface of 14.65 $\mathrm{km}^{2}$, and a mean annual rain of $1,340 \mathrm{~mm}$. It contributes to the Mogi-Guaçu/Pardo river basin. This watershed contains fragments of the semideciduous tropical forest at the highest altitudes, and the Cerrado vegetation at the lowest levels, with the main area occupied by extensively and intensively managed pastureland and forage fields, in which cattle graze in the rainy season, and sugar cane and maize fields for silage to feed cattle in the winter dry season.

Sampling point 1: spring in the tropical forest, but near pastureland; point 2 : spring in pastureland occupied by intensively managed dairy cattle, with high input of nitrogen, phosphate and limestone, and high stocking rate, protected by a $50-\mathrm{m}$ riparian belt established in 1993; point 3: dam spring, $500 \mathrm{~m}$ downwards point 2; point 4 : stream water, $1,500 \mathrm{~m}$ downwards point 1 , and point 5 : dam spring, 1,000 $\mathrm{m}$ downwards point 3, both affected by cattle, agricultural and urban activities; point 6: stream water near the mouth of the creek, affected by pastureland, after two waterfalls straight after points 4 and 5 , and presence of riparian vegetation along this water course. There is no riparian vegetation before the waterfalls. Soils (Hapludox: points 1, 2, 3; Eutrudox; Paleudalf: points 4, 5; and Aquic Quartzipsamment: point 6) washed by the water showed $30 \%$ to $60 \%$ aggregated clay, and low to high fertility (Calderano Filho et al., 1998). Both dams were strongly affected by sediment deposition.

These points were selected in order to provide data on water quality of the exported water from this watershed, and to draw a picture of variability of these so considered extremely managed areas.

\section{The variables}

From 03/13/96 to 03/14/99, the following variables were monitored: total coliforms (COL; most probable number $100 \mathrm{~mL}^{-1}$ ), fecal coliforms (FCOL; most probable number $100 \mathrm{~mL}^{-1}$ ), chemical oxygen demand (COD; $\mathrm{mg} \mathrm{L}^{-1}$ oxygen; sample digestion with concentrated solution of potassium dichromate + sulfuric acid), biochemical oxygen demand $\left(\mathrm{BOD}_{5} ; \mathrm{mg} \mathrm{L}^{-1}\right.$ oxygen; 5 days incubation ), oxygen consumption (OXCO; $\mathrm{mg} \mathrm{L}^{-1}$ oxygen; digestion with potassium permanganate + sulfuric acid), dissolved total organic carbon (TOC; $\mathrm{mg} \mathrm{L}^{-1}$ carbon), water temperature (TEMP; degrees Celsius), water hidrogenionic potential $(\mathrm{pH})$, alkalinity (ALCA; $\mathrm{mg} \mathrm{L}^{-1} \mathrm{CaCO}_{3}$ ), total hardness (HARD; $\mathrm{mg} \mathrm{L}^{-1}$ $\mathrm{CaCO}_{3}$ ), electric conductivity (COND; $\mu \mathrm{S} \mathrm{cm}^{-1}$ ), dissolved chloride (CHLO, mg L ${ }^{-1}$ ), nitrate-N (N$\mathrm{NO}_{3} ; \mathrm{mg} \mathrm{L} \mathrm{L}^{-1}$ ), total phosphorus, after sample digestion with potassium persulphate, as phosphate $\left(\mathrm{PO}_{4} ; \mathrm{mg} \mathrm{L}^{-1}\right)$, total iron $\left(\mathrm{Fe} ; \mathrm{mg} \mathrm{L}^{-1}\right)$, total manganese $\left(\mathrm{Mn} ; \mathrm{mg} \mathrm{L} \mathrm{L}^{-1}\right)$, apparent color (ACO; $\mathrm{mg} \mathrm{L}^{-1}$ platinum-cobalt), true color (TCO; $\mathrm{mg} \mathrm{L}^{-1}$ platinum-cobalt; as a result of ACO minus the impurities which cause the turbidity), turbidity (TUR; NTU); sedimented solids (SEDS; $\mathrm{mL} \mathrm{L}^{-1}$ ), total solids (TOTS; $\mathrm{mg} \mathrm{L}^{-1}$ ), stable solids in suspension (SUFS; $\mathrm{mg} \mathrm{L}^{-1}$ ), volatile solids in suspension (SUVS; $\mathrm{mg} \mathrm{L} \mathrm{L}^{-1}$ ), stable dissolved solids (DIFS; $\mathrm{mg} \mathrm{L}^{-1}$ ), and volatile dissolved solids (DIVS; $\mathrm{mg} \mathrm{L}^{-1}$ ).

At each second Tuesday of the month, between 8:30 and 10:30 a.m., one water sample from each of the six points was collected and kept in a sterilized $200 \mathrm{~mL}$ glass bottle for COL and FCOL determination, and a $2 \mathrm{~L}$ plastic bottle for analyses of the other variables. Immediately after sampling, samples were carried to the lab to be submitted to the biological, chemical and physical analyses, according to the methods described by APHA (1992).

Rain volume (mm) 3 days before the sampling date was recorded. 


\section{Descriptive statistics}

To remove scale effects, the observed data $\left(y_{\mathrm{i}}, \mathrm{i}=\right.$ $1,2 \ldots, n)$ were standardized to $z_{i}=\left(y_{i}-\ddot{y}_{i}\right) / \sigma$, where $\mathrm{z}_{\mathrm{i}}$ is normally distributed, " $\ddot{\mathrm{y}}_{\mathrm{i}}$ " is the mean and " $\sigma$ " the standard deviation.

Pearson correlation (SAS Institute, 1993) was calculated to verify relationship among variables.

\section{Principal component analysis (PCA)}

The PCA technique, using a correlation matrix (SAS Institute, 1993), was applied to verify relationships among variables. The plot of the first two components was considered to identify association among variables and sampling points.

Table 1 - Means of variables analyzed at six sampling points, and global mean, minimum and maximum values.

\begin{tabular}{|c|c|c|c|c|c|c|c|c|c|c|}
\hline \multicolumn{2}{|c|}{ Variables } & \multirow[t]{2}{*}{1} & \multirow{2}{*}{2} & 3 & 4 & 5 & \multirow[t]{2}{*}{6} & \multicolumn{3}{|c|}{----------- global --------------- } \\
\hline & & & & & ean - & & & mean & minimum & maximum \\
\hline $\mathrm{COL}$ & MPN $100 \mathrm{~mL}^{-1}$ & 1,749 & 4,491 & 7,434 & 24,399 & 28,026 & 12,866 & 13,161 & 0 & $\overline{241,920}$ \\
\hline FCOL & MPN $100 \mathrm{~mL}^{-1}$ & 7 & 458 & 243 & 1562 & 1468 & 630 & 728 & 0 & 8600 \\
\hline COD & $\mathrm{mg} \mathrm{L}^{-1} \mathrm{O}_{2}$ & 0.7 & 8.0 & 10.4 & 13.7 & 15.9 & 11.3 & 10.0 & 0 & 67.0 \\
\hline BOD & $\mathrm{mg} \mathrm{L}^{-1} \mathrm{O}_{2}$ & 0.3 & 1.4 & 2.3 & 3.2 & 3.1 & 2.2 & 2.1 & 0 & 32.0 \\
\hline OXCO & $\mathrm{mg} \mathrm{L}^{-1} \mathrm{O}_{2}$ & 0.1 & 1.9 & 2.4 & 2.5 & 2.6 & 2.1 & 1.9 & 0 & 10.0 \\
\hline TOC & $\mathrm{mg} \mathrm{L}^{-1} \mathrm{C}$ & 3.5 & 4.1 & 4.6 & 4.6 & 4.8 & 3.7 & 4.2 & 0.3 & 14.7 \\
\hline TEMP & ${ }^{\circ} \mathrm{C}$ & 21.9 & 21.0 & 22.2 & 21.4 & 21.8 & 20.9 & 21.6 & 15.5 & 27.0 \\
\hline $\mathrm{pH}$ & & 5.4 & 5.6 & 6.4 & 6.5 & 6.5 & 6.5 & 6.2 & 4.2 & 7.4 \\
\hline ALCA & $\mathrm{mg} \mathrm{L}^{-1} \mathrm{CaCO}_{3}$ & 4.6 & 4.4 & 10.7 & 12.9 & 12.4 & 13.0 & 9.7 & 0 & 18.0 \\
\hline HARD & $\mathrm{mg} \mathrm{L}^{-1} \mathrm{CaCO}_{3}$ & 1.1 & 1.4 & 6.3 & 9.2 & 8.8 & 8.4 & 5.9 & 0 & 12.0 \\
\hline COND & $\mu \mathrm{S} \mathrm{cm}^{-1}$ & 11.2 & 6.1 & 16.5 & 25.6 & 23.6 & 23.3 & 17.7 & 4.0 & 31.6 \\
\hline CHLO & $\mathrm{mg} \mathrm{L}^{-1} \mathrm{Cl}$ & 0.4 & 0.6 & 0.8 & 1.8 & 1.5 & 1.3 & 1.1 & 0 & 19.0 \\
\hline $\mathrm{NO}_{3}$ & $\mathrm{mg} \mathrm{L}^{-1} \mathrm{~N}$ & 0.3 & 0.3 & 0.3 & 0.8 & 0.7 & 0.6 & 0.5 & 0 & 5.1 \\
\hline $\mathrm{PO}_{4}$ & $\mathrm{mg} \mathrm{L}^{-1} \quad \mathrm{PO}_{4}$ & 0.018 & 0.039 & 0.120 & 0.102 & 0.103 & 0.070 & 0.076 & 0 & 0.800 \\
\hline $\mathrm{Fe}$ & $\mathrm{mg} \mathrm{L}^{-1} \mathrm{Fe}$ & 0.1 & 0.5 & 0.2 & 1.4 & 1.0 & 1.0 & 0.7 & 0 & 4.0 \\
\hline $\mathrm{Mn}$ & $\mathrm{mg} \mathrm{L}^{-1} \quad \mathrm{Mn}$ & 0.003 & 0.003 & 0.004 & 0.016 & 0.013 & 0.006 & 0.008 & 0 & 0.120 \\
\hline $\mathrm{ACO}$ & $\mathrm{mg} \mathrm{L}^{-1} \mathrm{Pt}$ & 3.2 & 34.4 & 54.1 & 112.5 & 80.7 & 68.4 & 58.9 & 1.0 & 400.0 \\
\hline TCO & $\mathrm{mg} \mathrm{L}^{-1} \mathrm{Pt}$ & 2.5 & 12.1 & 22.9 & 52.0 & 38.0 & 34.1 & 27.0 & 1.0 & 133.0 \\
\hline TUR & NTU & 0.4 & 6.9 & 9.5 & 20.7 & 13.4 & 14.0 & 10.8 & 0.1 & 68.0 \\
\hline SEDS & $\mathrm{mL} \mathrm{L}^{-1}$ & 0.000 & 0.172 & 0.008 & 0.097 & 0.025 & 0.075 & 0.063 & 0 & 2.500 \\
\hline TOTS & $\mathrm{mg} \mathrm{L}^{-1}$ & 20.5 & 28.6 & 40.5 & 45.0 & 36.7 & 42.6 & 35.6 & 4.0 & 168.0 \\
\hline SUFS & $\mathrm{mg} \mathrm{L}^{-1}$ & 1.4 & 5.3 & 5.3 & 7.8 & 4.7 & 7.1 & 5.3 & 1.0 & 37.0 \\
\hline SUVS & $\mathrm{mg} \mathrm{L}^{-1}$ & 1.2 & 3.8 & 4.9 & 4.8 & 4.6 & 4.3 & 3.9 & 0.4 & 16.0 \\
\hline DIFS & $\mathrm{mg} \mathrm{L}^{-1}$ & 6.0 & 6.5 & 8.3 & 11.1 & 10.7 & 12.3 & 9.1 & 1.0 & 71.0 \\
\hline DIVS & $\mathrm{mg} \mathrm{L}^{-1}$ & 11.8 & 13.1 & 22.0 & 21.4 & 16.7 & 18.9 & 17.3 & 1.0 & 90.0 \\
\hline
\end{tabular}

Obs: MPN = most probable number. $\mathrm{PO}_{4} \times 0.326=\mathrm{P}, \mathrm{mg} \mathrm{L}^{-1}$; $\mathrm{ALCA}: \mathrm{mg} \mathrm{L}^{-1} / 50=$ meq L $\mathrm{L}^{-1} \mathrm{CaCO}_{3}$.

\section{RESULTS AND DISCUSSION}

Table 1 shows the original mean values of the variables monitored during 36 months, at six sampling points, as well as the overall mean, minimum and maximum values of each variable. Point 1 presented the lowest mean for most of the variables and point 4 the highest. These results were also confirmed in Figure 1, which showed the distribution in time of the standardized values of some variables. The sampling points were better discriminated by: COND followed by $\mathrm{Fe}$, TUR, ACO, $\mathrm{pH}$, ALCA, HARD and $\mathrm{NO}_{3}$.

Pearson correlation analysis showed that the variables FCOL and COL, and DIFS and DIVS were strongly correlated $(\mathrm{P}<0.01)$ and were independent of the others. Variables TOC, TEMP, $\mathrm{Mn}, \mathrm{PO}_{4}, \mathrm{NO}_{3}, \mathrm{SEDS}, \mathrm{BOD}$ and TCO did not show correlation $(\mathrm{P}>0.05)$ among them and the other variables. The remaining variables showed medium to high correlation, and were submitted to PCA. 



Figure 1 - Monthy (1 to 36: Mar96/Mar97, Apr97/Mar98, apr98/Mar99) distribution of the standardized water characteristics, of six sampling points 1. Forest spring (line), 2. Pasture spring (triangle), 3. Upper dam spring (circle), 4. Upward stream (square), 5. Dam spring below (plus) and 6. Delta stream (dot.). 
The PCA (Table 2) summarized appropriately the data; $74 \%$ of the total variance associated to the data was explained by the first three components, and only the first component explained 53\% of the whole variability of the data. The second component, which explained $14 \%$ of total variability, emphasized the effect of variables SUFS, SUVS followed by COD, FCOL and OXCO mainly referred to fractions in suspension.

Figure 2, shows two first principal components and thirteen variables for the six sampling points during 36 months. First component (Prin1) had increasing values of TCO, TUR, ACO, HARD, COND, ALCA, $\mathrm{pH}$, and $\mathrm{Fe}$, from left to right, and second component (Prin2) had increasing values of SUFS, SUVS, and COD, from bottom to top. There was a clear difference among sampling points 1, 2 and 4, and similarities among points 3,5 and 6 . Points 1 and 4 showed extreme values.

Table 2 - Autovalues of the principal component.

\begin{tabular}{lcccc}
\hline Component & Autovalue & Difference & Proportion & Accumulated \\
\hline $1^{\text {st }}$ & 6.93 & 5.13 & 0.53 & 0.53 \\
$2^{\text {nd }}$ & 1.80 & 0.86 & 0.14 & 0.67 \\
$3^{\text {rd }}$ & 0.94 & 0.15 & 0.07 & 0.74 \\
$4^{\text {th }}$ & 0.80 & 0.20 & 0.06 & 0.81 \\
$5^{\text {th }}$ & 0.59 & 0.11 & 0.05 & 0.85 \\
\hline
\end{tabular}

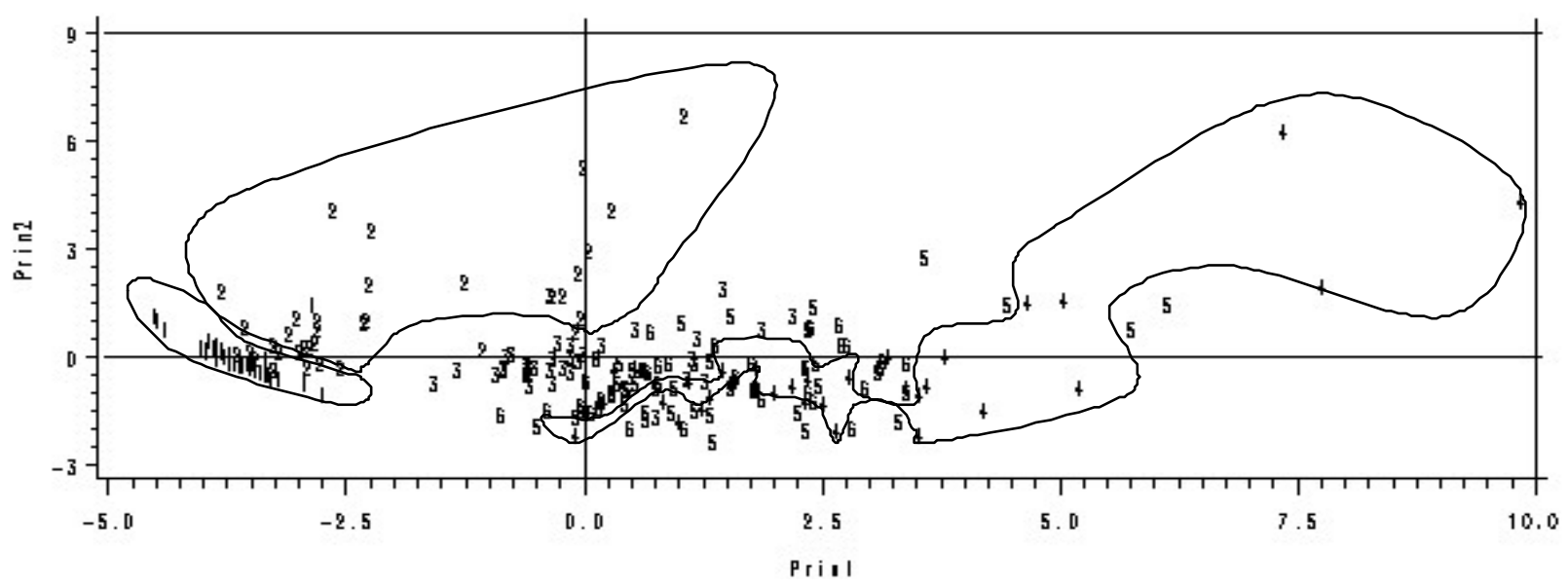

Figure 2 - Plot of the principal components 1 and 2, and identification of the six sampling points.

The spring in the forest (point 1) showed lowest values for the variables, and lowest variability along time. Point 4 showed highest monthly fluctuation for the variables. This point was exposed to agricultural activities, and was less protected than point 5 . The variability found in water quality at the spring in intensive dairy production system (point 2) and relatively higher value stability at the dam downwards (point 3) were a surprise, considering that both were protected by a 50-m riparian belt, perhaps insufficient to protect spring areas. The sampling point with the highest values of TUR, $\mathrm{Fe}, \mathrm{NO}_{3}$, BOD and FCOL was point 4 , followed by points 5 ,
6, and 3 (Table 1 and Figure 1). Higher $\mathrm{PO}_{4}$ values were found in point 3 , followed by points 4,5 and 6 . Behavior of point 3 was probably related with the $50-\mathrm{m}$ protection strip at the margins, with intense grass development, and recovering of the riparian forest acting as a filter, but not efficiently retaining $\mathrm{PO}_{4}$. The single correlation analysis at point 3 resulted significant when $\mathrm{PO}_{4}$ was related to ACO (r=0.71, $\mathrm{P}<0.01), \mathrm{OXCO}(\mathrm{r}=0.66, \mathrm{P}<0.01)$ and $\mathrm{Fe}(\mathrm{r}=0.47, \mathrm{P}<0.05)$, suggesting the presence of some process including reduced materials or some biological activity or some delayed release of $\mathrm{PO}_{4}$. The increased surface application of phosphates and limestone in the dairy production 
system, located on the drainage area of points 2 and 3 could saturate or neutralize adsorption sites, allowing perhaps losses of $\mathrm{PO}_{4}$ from the area. Initial value of available phosphorus at the soil surface $(5 \mathrm{~cm})$, was $2 \mathrm{mg} \mathrm{kg}^{-1}$, rising up to $150-\mathrm{mg}$ $\mathrm{kg}^{-1}$ after intensive input use. At the same place an increase of forage biomass production, as well as increase of stocking rate and feces production occured. Feces seemed to be retained by the riparian vegetation as indicated by the FCOL values. This suggested an intense $\mathrm{PO}_{4}$ transport in dissolved form (Brunet \& Astin, 1998), and the need of more specific studies on interactions that occurred on the path from application sites and water bodies and also the preferential water flow paths. On the other hand, water bodies at points 4 and 5 were more intensively available to access of animals (mainly wild ones, like Hidrocoeris hydrocoeris), and the punctual discharge of domestic septic pits, or feces from areas with larger animal population, besides a poor protection by a riparian strip, and the punctual discharge of the preferential surface water flow, like ways and animal paths.
Considering $\mathrm{pH}$, ALCA and HARD, there was a clear distinction among springs and the other points (Figure 1). COND was the clearest discriminator of the sampling points, without strong rain interference, perhaps due to the main influence of chemical characteristics of surrounding soils, such as suggested by the $\mathrm{Fe}$ data, whose oxide was a main parameter to discriminate the different Oxisols (Calderano Filho et al., 1998).

According to the state environmental legislation (São Paulo, 1977), the water of the Canchim's creek is classified as class 2 freshwater (COND < $750 \mu \mathrm{S} \mathrm{cm}^{-1}$, or total dissolved solids - TDS $<500$ $\mathrm{mg} \mathrm{L}^{-1}$ ). Comparing the obtained results (Table 1) with Brazilian standards and environmental legislation for class 2 freshwater (Table 3) (Agudo, 1987), creek's water at the mouth fitted well with most of the quality parameters, except for $\mathrm{PO}_{4}$ and Fe. Peaks of FCOL, BOD and ACO, and also $\mathrm{Fe}$ values allowed for class 3 , besides mean values of $\mathrm{PO}_{4}$. Water at point 1 could be considered drinkable (provided treated to control FCOL).

Table 3 - Upper limit parameters to qualify freshwater.

\begin{tabular}{lrrrrrrrrrrr}
\hline Class & FCOL & BOD & OXCO & TUR & ACO & TDS & CHLO & FE & MN & $\mathrm{N}_{-N_{3}}$ & $\mathrm{P}_{-P_{4}}$ \\
\hline & MPN & $\mathrm{mg} \mathrm{L}^{-1}$ & $\mathrm{mg} \mathrm{L}^{-1}$ & UNT & $\mathrm{mg} \mathrm{L}^{-1}$ & $\mathrm{mg} \mathrm{L}^{-1}$ & $\mathrm{mg} \mathrm{L}^{-1}$ & $\mathrm{mg} \mathrm{L}^{-1}$ & $\mathrm{mg} \mathrm{L}^{-1}$ & $\mathrm{mg} \mathrm{L}^{-1}$ & $\mathrm{mg} \mathrm{L}^{-1}$ \\
1 & $*, * *$ & $<3$ & - & $<40$ & - & $<200$ & $<250$ & $<0.3$ & $<0.10$ & $<10$ & $<0.025$ \\
2 & $<1,000$ & $<5$ & - & $<100$ & $<75$ & $<200$ & $<250$ & $<0.3$ & $<0.10$ & $<10$ & $<0.025$ \\
3 & $<4,000$ & $<10$ & - & $<100$ & $<75$ & $<500$ & $<250$ & $<5.0$ & $<0.50$ & $<10$ & $<0.025$ \\
drinkable 1 & 0 & - & $<10$ & $<5$ & $<20$ & $<500$ & $<250$ & $<0.3$ & $<0.50$ & $<10$ & - \\
drinkable 2 & 0 & - & $<2.0$ & $<5$ & $<5$ & $<500$ & $<100$ & $<0.3$ & $<0.05$ & $<2$ & - \\
drinkable 3 & 0 & - & $<3.5$ & $<10$ & $<30$ & $<500$ & $<250$ & $<0.3$ & $<0.05$ & $<2$ & - \\
\hline
\end{tabular}

*for consumption $=0$, ** for vegetable irrigation $<200 ;$ TDS $=$ total dissolved solids $=$ DIVS+DIFS.

drinkable $1 / 2 / 3=$ public supply/spring/well; $\mathrm{P}=\mathrm{PO} 4$ x 0.326 .

Source: Agudo, 1987 (CONAMA Resolution N.20 of 6/18/86).

So far as COD was concerned, Teixeira (1993) reported about values within 0 and $174 \mathrm{mg} \mathrm{L}^{-1}$, while for TUR, Salati (1996) recorded maximum values of 999 NTU, and Maier (1987) from 4 to 91 NTU, all higher than the values here described.

In this watershed, the low $\mathrm{pH}$ values of the spring water were a distinction, perhaps due the low values of ALCA and HARD (Table 1), resulting in a corrosive water for all metallic containers and hydraulic ducts. This water needed to be treated chemically to make it suitable (Loewenthal \& Marais, 1976), increasing the $\mathrm{pH}$ to a level of 8.5 to 9.0. In the region, Santos (1993a) found $\mathrm{pH}$ values from 7.1 to a minimum of 4.2 , suggesting that this value was due to a fast decomposition rate of the litter of the riparian forest and other organic materials. ALCA, which seemed to be related to $\mathrm{pH}$, showed mean values from 0.08 to 0.26 , with a maximum of $0.34 \mathrm{me} \mathrm{L}^{-1}$, in the lower range of values in regional waters (Teixeira, 1993) 0 to $1.47 \mathrm{me} \mathrm{L}^{-1}$, (Salati, 1996) 0.16 to $0.94 \mathrm{me} \mathrm{L}^{-1}$ (=8 to $47 \mathrm{mg} \mathrm{L}^{-1}$ ), with mean values of $0.35 \mathrm{me} \mathrm{L}^{-1}$.

From the irrigation point of view - to avoid salinization - the appropriate values for COND needed to be lower than $750 \mu \mathrm{S} \mathrm{cm}^{-1}$ (Reichardt, 1978). This value did not exceed in any of the six monitored sampling points, in spite of the increased levels near fertilized areas, compared to the forest spring water. From the environmental point of view, the values in this watershed 
remained low compared to values of other regional waters: minimum of $13 \mu \mathrm{S} \mathrm{cm}$ and mean of 86 $\mu \mathrm{S} \mathrm{cm}^{-1}$ (Santos, 1993b), or a minimum of $12 \mu \mathrm{S}$ $\mathrm{cm}^{-1}$ and a maximum from 147 to $250 \mu \mathrm{S} \mathrm{cm}^{-1}$ (Teixeira, 1993), or extreme values within 2 and $300 \mu \mathrm{S} \mathrm{cm}^{-1}$, with mean values from 12 to $75 \mu \mathrm{S}$ $\mathrm{cm}^{-1}$ (Maier et al., 1986). The fact that COND discriminated well the sampling points, in spite of low values, was also observed by Rios \& Calijuri (1995) and Branco \& Necchi (1997).

The $\mathrm{PO}_{4}$ levels, except at the forest spring (oligotrophic), were higher than that established as environmentally acceptable (Agudo, 1987), moving in the range from the trophic index state considered as eutrophic ( 27 to $52 \mu \mathrm{g} \mathrm{L}^{-1} \mathrm{P}$ ), with peaks reaching the hypertrophic (>212 $\mu \mathrm{g} \mathrm{L}^{-1} \mathrm{P}$; Toledo Jr. et al., 1983). In regional water bodies, the values measured for total $\mathrm{PO}_{4}$ were at a maximum of $420 \mu \mathrm{g} \mathrm{L}^{-1}$ (Santos, 1993b), $800 \mu \mathrm{g}$ $\mathrm{L}^{-1}$ (Santos, 1993a) and $1,137 \mu \mathrm{g} \mathrm{L}^{-1}$ (Teixeira, 1993), against a minimum of $5 \mu \mathrm{g} \mathrm{L}^{-1}$ (Teixeira, 1993). More research is needed to study the processes involved in the losses of phosphate, which seems to be the main problem for water quality, and whose control is not well dominated.

Although PCA excluded the variable NO3, the curves in Figure 1 showed that it was local dependent, and that rain dependent losses were occurring. Further studies are needed to disclose $\mathrm{N}$ dynamic on agricultural areas and its impact on water bodies. In this study, the maximum values were below the maximum allowed limits, even at point 3 in whose drainage area an intensive use of nitrogen fertilizers occurred. Teixeira (1993) found values within 0.02 and $0.38 \mathrm{mg} \mathrm{L}^{1}$, Santos (1993b) found maximum values of $3 \mathrm{mg} \mathrm{L}$, and Santos (1993a) $5.1 \mathrm{mg} \mathrm{L}^{1}$ (mean of $0.4 \mathrm{mg} \mathrm{L1}$ ). Salati (1996) found higher levels in winter (0.04 to $0.67 \mathrm{mg} \mathrm{L1})$ than in summer $(0.18$ to $0.39 \mathrm{mg} \mathrm{L} 1)$, what seemed to be related to the rainy season (Rain; Figure 1).

With respect to the variable TOC (total organic carbon), it was not easy to evaluate and establish tolerance classes, considering that it does not discriminate between harmless and toxic organic molecules. At the forest spring, considered without or with low impact, the mean values were not different from the other sampling points (Table 1). Sometimes the spring water showed higher values, like at the beginning (Figure 1, month 3 to 6), perhaps due to the input of root exsudates and organic molecules of the decaying litter. The second peak (month 16), at the spring water, could be explained by the contamination of the ground water by organic molecules washed through dry period soil cracks. Santos (1993b) found values of $16 \mathrm{mg} \mathrm{L}^{-1}$, Teixeira (1993) of $19 \mathrm{mg} \mathrm{L}^{-1}$, and Salati (1996) values within 2 and $17 \mathrm{mg} \mathrm{L}^{-1}$, values similar to those found in this study.

\section{CONCLUSIONS}

a) Class 2 freshwater of Canchim's creek fitted well with legislation standards, except for phosphorus and iron.

b) Water of the forest spring used for human consumption needed to be treated, because of occasional presence of fecal coliforms.

c) The phosphorus level in the waterbodies turned them eutrophic, mainly at the points with greater anthropogenic impact, being a potential indicator of the degree of agricultural management.

d) A relation between the nitrate level and more intensively managed agricultural areas could not be found.

e) Dissolved total organic carbon was not an adequate variable to point out the presence of harmful organic molecules in the ecosystem.

f) The variables, which better discriminated the sampling points, and their protection degree, were: true color, hardness, turbidity, electric conductivity, alkalinity, $\mathrm{pH}$, and chemical oxygen demand.

\section{RESUMO}

Foi escolhida a microbacia hidrográfica do ribeirão Canchim, em São Carlos, SP, para avaliar a qualidade da água próxima a sistemas de produção de bovinos de leite e corte pastejando forrageiras tropicais. As amostras de água foram coletadas mensalmente de seis pontos de coleta: nascente em mata, nascente em sistema intensivo de produção de bovinos de leite, dois vertedouros de açude e em água corrente a montante e na foz do ribeirão. Resultados de três anos mostraram diferenças $(\mathrm{P}<0,01)$ entre os pontos de coleta para as principais variáveis. Cor verdadeira, dureza, turbidez, condutividade elétrica, alcalinidade, $\mathrm{pH}$, demanda química de oxigênio e oxigênio consumido explicaram bem essas diferenças. De acordo com os padrões da legislação vigente, a 
qualidade da água enquadra-se na classe 2 para a maioria dos parametros, com exceção de fosforo total e ferro. Os niveis elevados de fósforo total, exceto na nascente da mata, enquadram estas águas na classe eutrófica, mesmo onde as práticas de conservação de água e solo foram consideradas adequadas. Pesquisa continua sobre o problema.

\section{REFERENCES}

Agudo, E. G. (coord.) (1987), Guia de coleta e preservação de amostras de água, $1^{\text {st }}$ ed. CETESB : São Paulo. 150 pp.

APHA (1992), Standard Methods: for the examination of water and waste water. Washington, DC, American Public Health Association/American Water Works Association/Water Environmental Federation. $18^{\text {th }}$ ed. 1354 pp.

Branco, L. H. Z. and Necchi Jr., O. (1997), Variação longitudinal de parâmetros físicos e químicos em três rios pertencentes a diferentes bacias de drenagem na região noroeste do estado de São Paulo. Acta Limnologica Brasiliensia, 9, 165-177.

Brunet, R. C. and Astin, K. B. (1998), Variation in phosphorus flux during a hydrological season: the river Adour. Water Research, 32 : (3), 547-558.

Calderano Filho, B.; Santos, H. G. dos; Fonseca, O. O. M. da; Santos, R. D. dos; Primavesi, O. and Primavesi, A. C. (1998), Os solos da fazenda Canchim, Centro de Pesquisa de Pecuária do Sudeste, São Carlos, SP: Levantamento semidetalhado, propriedades e potenciais. Rio de Janeiro : EMBRAPA-CNPS. 95 pp. (Research Bulletin; 7).

Chokmani, K. and Gallinchand, J. (1997), Use of indices to evaluate the diffuse pollution potential at two agricultural catchment basins. Canadian Agricultural Engeneering, 39 : (2), 113-122.

Cornish, P. S.; Baginska, B.; Kuczera, G.; Jones, D. and Mohammad, A. (1996), Measuring the effects of land use and land management on river water quality. Paper presented at $8^{\text {th }}$ Australian Agronomy Conference, Toowoomba, Queensland, Australia. Proceedings... Toowoomba, Australia: Australian Society of Agronomy. pp. 152-159.

Edwards, D. R.; Coyne, M. S.; Vendrell, P. F.; Daniel, T. C.; Moore Jr. and Murdoch, J. F. (1997), Fecal coliform and streptococcus concentrations in runoff grazed pastures in northwest Arkansas. Journal of the American Water Resources Association, 33 : (2), 413-422.

Heathwaite, A. L. and Johnes, P. J. (1996), Contribution of nitrogen species and phosphorus fraction to stream water quality in agricultural catchments. Hydrological Processes, 10 : (7), 971-983.
Howell, J. M.; Coyne, M. S. and Cornelius, P. (1995), Fecal bacteria in agricultural waters of the bluegrass region of Kentucky. Journal of Environmental Quality, 24 : (3), 411-419.

Jaworski, N. A.; Groffman, P. M.; Keller, A. A. and Prager, J. C. (1992), A watershed nitrogen and phosphorus balance: the upper Potomac river basin. Estuaries, 15 : (1), 83-95.

Johnes, P.; Moss, B. and Phillips, G. (1996), The determination of total nitrogen and total phosphorus concentration in freshwaters from land use, stock headage and population management. Freshwater Biology, 36 : (2), 451-473.

Loewenthal, R. E. and Marais, G. V. R. (1976), Carbonate chemistry of aquatic systems: theory and applications, Ann Arbor Science Pub Inc, Ann Arbor, Michigan. 405 pp.

Maier, M. H.; Takino, M.; Basille-Martins, M. A. and Cipolli, M. N. (1986), River tipology of São Paulo State, Brazil. Verh. Internat. Verein Limnol., 22, 2161-2166.

Maier, M. H. (1987), Ecologia da bacia do Rio Javaré

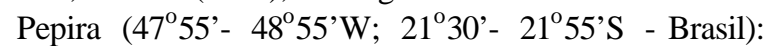
qualidade da água do rio principal. Ciência e Cultura, 39, 164-185.

Nash, D. and Murdoch, C. (1997), Phosphorus in runoff from a fertile dairy pasture. Australian Journal of Soil Research, 35 : (2), 419-429.

Reichardt, K. (1978), A água na produção agrícola. São Paulo : McGraw-Hill Brasil. 119 pp.

Rios, L. (1993), Estudo limnológico e fatores ecológicos em ribeirões e córregos da bacia hidrográfica do ribeirão do Feijão (Estado de São Paulo). Master of Science dissertation. São Carlos : EESC/USP. $146 \mathrm{pp}$

Rios, L. and Calijuri, M. do C. (1995), A bacia hodrográfica do ribeirão do Feijão: uma proposta de ordenação das sub-bacias através de variáveis limnológicas. Acta Limnologica Brasiliensia, 7, 151-161.

Salati, E. (1996), Diagnóstico ambiental sintético e qualidade da água como subsídio para o planejameto regional integrado da bacia hidrográfica do rio Corumbataí (SP). $\mathrm{PhD}$ Thesis. São Carlos : CHREA/EESC/USP. 199 pp.

Santos, M. F. (1993a), Subsídios para o planejamento conservacionista da Bacia Hidrografica do Ribeirão do Feijão (São Carlos, Itirapina and Analândia, SP). São Carlos. Master of Science Dissertation. São Carlos : CRHEA/EESC/USP. 222 pp.

Santos, M. J. (1993b), Estudo limnológico dos córregos da Água Fria e da Água Quente. Master of Science dissertation. São Carlos : CHREA/EESC/USP. $291 \mathrm{pp}$.

São Paulo (1997), Diário Oficial do Estado de São Paulo: decreto $10.755,11 / 22 / 1977$.

SAS Institute (1993), SAS/STAT User's guide: statistics, version 6.4, Sas Inst, Cary. 1686 pp. 
Sé, J. A. S. (1992), O rio Monjolinho e sua bacia hidrográfica como integrantes de sistemas ecológicos. Master of Science Dissertation. São Carlos : CHREA/EESC/USP. 381 pp.

Teixeira, D. (1993), Caracterização limnológica dos sistema lóticos e variação temporal e espacial de invertebrados bênticos na bacia do ribeirão do Feijão (São Carlos, SP). Master of Science Dissertation. São Carlos : CRHEA/EESC/USP. 193 pp.
Toledo Jr., A. P. de; Chinez, S. J. and Agudo, E. G. (1983), A aplicação de modelos simplificados para a avaliação do processo de eutrofização em lagos e reservatórios tropicais. Paper presented at $12^{\text {th }}$ Brazilian Congress on Sanitation Engeneering and Environment (Congresso Brasileiro de Engenharia Sanitária e Ambiental), Balneário Camboriú, SC, 1983, São Paulo : CETESB. Deng, 22, 1-34.

Zhang, J. and Essex, A. (1997), Phosphorus load reduction from out-of-compliance sites in the lake Okeechobee watershed, Florida. Applied Engeneering in Agriculture, 13 : (2), 193-198.

Received: June 28, 2000; Revised: August 06, 2001; Accepted: November 29, 2001. 


\title{
PÁGINA
}

\author{
EM
}

BRANCO 